\title{
A Recepção Televisiva \\ e suas Mediações no Ensino Médio*
}

\author{
Magno Medeiros da Silva** \\ Pedro Plaza Pinto***
}

\begin{abstract}
Resumo
O artigo trata da teoria da recepção, que busca compreender os processos comunicativos e a construção do significado pelos receptores em uma escola pública (CEFET). Tem-se como pressuposto básico que os meios de comunicação não são meros meios de transporte de informação, mas revelam significados culturais criados num determinado período histórico.

Palavras-chave: meios de comunicação, recepção, audiência, educação para os meios.
\end{abstract}

\section{Introdução}

O presente texto sintetiza os resultados da pesquisa "Processos Midiáticos, Recepção e Educação”, apoiado pelo PIBIC/CNPq, no período compreendido entre setembro/99 a agosto/2000. Com o plano de trabalho denominado "Mediações e educação em face da mídia no ensino médio", a pesquisa procurou investigar o processo comunicativo a partir do receptor no ambiente escolar do CEFET Centro Federal de Educação Tecnológica, de Goiânia, particularmente com os alunos do $1^{\circ}$. ano médio.

* Trabalho apresentado no V SIPEC - Simpósio de Pesquisa em Comunicação do Centro-Oeste., realizado em Goiânia, no período de 20 a 22 de maio de 2000.

** Doutor pela USP, coordenador do GT Mídia e Recepção da Compós, professor da Faculdade de Comunicação e Biblioteconomia da UFG e docente participante do Programa de Pós-Graduação em Educação Brasileira da Faculdade de Educação da mesma universidade.

*** Bolsista do PIBIC/CNPq, acadêmico de Comunicação Social pela Universidade Federal de Goiás.

Comun. Inf., v. 3, n. 1, p. 80-98, jan./jun. 2000 
O objetivo desta pesquisa foi verificar e compreender, a partir de oficinas interativas, quais mediações poderiam ser relacionadas no processo midiático a partir do ponto de vista do receptor-sujeito. Esta composição substantiva "sujeito-receptor" poderia ser entendida como contraditória, uma vez que receptoré uma categoria geralmente associada à passividade, segundo o modelo hegemônico da sociologia funcionalista americana.

Entretanto, deve-se compreender essa aparente contradição como uma procura de rompimento com a concepção "etapista" e a proposição de que a recepção constitui-se numa espécie de metáfora de reencontro dos estudos da comunicação com a sociedade latino-americana de hoje (Martín-Barbero, 1994, p. 39).

No contexto dessa premissa, a hipótese pensada é a de que os alunos do grupo escolhido, receptores televisivos, não se colocam passivamente frente ao meio e devem ser entendidos na complexidade das "multimediações" que são inerentes ao ambiente educacional, oriundas das diversas relações estabelecidas pelos sujeitos nos processos comunicacionais. $\mathrm{O}$ trabalho desenvolveu a linha de que os adolescentes são capazes de tomar posicionamento frente ao meio, aos fatos noticiados ou às informações reportadas, tendo por base as mediações estabelecidas no processo midiático.

A problemática na relação prismática entre Comunicação, Educação e Novas Tecnologias encontra-se no centro do debate dos atuais estudos multidisciplinares das áreas afins no Brasil e na América Latina. $\mathrm{O}$ caso brasileiro passa pela legitimação de uma reforma substancial implementada nos últimos dois anos pela nova LDB-Lei de Diretrizes e Bases da Educação, que prevê a reformulação do Ensino Médio.

A norma legal deve estar em perspectiva nas pesquisas realizadas sobre o tema, uma vez que "fortalece-se o consenso de que uma adequada gestão da comunicação e da informação, (...) deixou de ser preocupação localizada de alguns poucos tecnólogos, transformando-se, ao contrário, em objeto de estudo e prática social" (Soares, 1998, p. 232).

O campo próprio onde se trabalha a Educação em face da Mídia é estabelecido na dialética entre busca e gestão da ação comunicativa. Contribuir numa ação democrática, criativa e participativa é o objetivo desta pesquisa, criticando as noções etapistas de controle dos sujeitos do processo da comunicação.

Comun. Inf., v. 3, n. 1, p. 80-98, jan./jun. 2000 


\section{A Educação em face da Mídia e das múltiplas mediações}

A partir da metade deste século vem se consolidando uma mudança de foco na orientação de visualização das mídias, com preocupações educacionais em relação à ideologia e aos conteúdos explícitos e implícitos na cultura de massa. Entretanto, essa perspectiva universalista estava acompanhada de teorias de sociedade è de uma Teoria da Informação condutista, que ainda propunham o controle, quando não a idéia de uma manipulação possível. A reorientação propõe um sentido diverso, centrado num receptor ativo e nas múltiplas mediações inseridas no processo.

De uma pedagogia do controle passamos para uma pedagogia da educação para os meios, ou, como preferimos, Educação em face da Mídia. É esse contexto de passagem de afirmação e configuração de um campo que aproxima, na segunda metade da década de 90 , educação e novas tecnologias. É uma mudança de prática educativa na comunicação na América Latina, decorrida de uma revisão conceitual e programática. A mídia seria compreendida como a própria intermediação na produção da cultura.

A expressão "Educação em face da Mídia" é uma variação nãoinstrumental daquela empregada por pesquisadores latino-americanos: "Educação para os Meios".É uma linha de pesquisa característica da América latina cujo objetivo é "potenciar a capacidade receptiva dos indivíduos-cidadãos na perspectiva de uma interação crítica, ética, estética, axiológica e propedêutica do processo comunicativo" (Silva, 1999, p. 266). Busca-se um resgate do sujeito criativo e ativo frente aos meios de comunicação, identificando qual é o papel das partes e valorizando a relação na vida social.

Entendemos a investigação sobre a recepção de maneira que abranja um grande campo, que busca compreender os usos sociais que fazem os sujeitos no processo de comunicação. A pergunta já deve ser uma mudança no eixo: o que faz a audiência com a informação e seus meios, como se relacionam? Também deve versar, de forma não menos importante, sobre o papel do "jogo da cultura" e das instituições sociais como mediação social no processo.

O trabalho de investigação da recepção é operado conectado com a Educação em face da Mídia, e deve configurar objetos que possam ser explorados produtivamente, pois o modelo para tal objetivação visa a estimular a utilização para novas aprendizagens

Comun. Inf., v. 3, n. 1, p. 80-98, jan./jun. 2000 
(Orozco Gómez, 1992, p. 292). A investigação da recepção busca entender:

- o que fazem os membros da audiência com os meios e as informações e como se relacionam entre si;

- qual é o papel da cultura e das instituições na mediação dos processos receptivos.

O forjamento do termo "mediação" no contexto da pesquisa sobre recepção e a presença do massivo no popular ocorrem numa perspectiva histórica de ruptura. É um dissensão sobre a validade do termo "cultura de massa". A proposta é mostrar o que se passa na cultura de emergência das massas necessariamente a partir da sua articulação com as readaptações da hegemonia.

A cultura é entendida como o espaço estratégico de negociação e realimentação das classes sociais. Segundo Martín-Barbero, "as invenções tecnológicas no campo da comunicação acham aí sua forma: o sentido que vai tomar sua mediação, a mutação da materialidade técnica em potencialidades comunicativas" (1997, 191). Investigar as mediações significa, então, investigar este processo naquilo que constitui suas apresentações materiais no ambiente da cultura.

A análise processual no eixo das mediações busca ser a superação dessa "fragmentação a que o processo de comunicação é submetido, e a partir da qual é pensado, controlando redutoramente o tipo de perguntas formuláveis, assim restringindo o universo do investigável e os modos de acesso aos problemas" (Martín-Barbero, 1997, p. 281). É uma valorização do cultural, remetendo à uma percepção de dimensões inéditas dos conflitos sociais, da presença dos sujeitos.

Entretanto, uma revisão teórica deixa lacunas que devemos preencher com asserções de vários estudiosos. Um problema atual é a definição mais exata possível do conceito de mediação. Afinal, do que trata este conceito tão utilizado nos estudos recentes sobre recepção na América Latina? O significado nãoé claro nem consensual (Signates, 1998, p. 44).

De fato, não é possível extrair concretamente o significado de mediação a partir das definições de Martín-Barbero. Será Orozco Gómez quem desenvolverá os marcos conceituais mais consistentes que servem de referência a este trabalho. Esses marcos não se sustentam em dicotomias, mas numa "busca epistemológica por um enfoque

Comun. Inf., v. 3, n. 1, p. 80-98, jan./jun. 2000 


\section{4}

integral da recepção, capaz de reunir em função da recepção televisiva a teoria da estruturação de Giddens, a teorização da mediação cultural de Martín-Barbero e sua própria conceituação de recepção e mediações como processo" (Signates, 1998, p. 44). Para tanto, Orozco Gómez desenvolve o conceito de múltiplas mediações.

Em primeiro lugar, de onde provêm as múltiplas mediações? Ao contrário do que se poderia pensar, as mediações provêm de diversas fontes, segundo Orozco Gómez: internas e externas, anteriores e posteriores ao processo comunicacional (Orozco Gómez, 1994, p. 297). Há mediações do tipo cognoscitivas, que dizem respeito à atenção e compreensão cotidiana, segundo hábitos próprios de conhecimento.

Outro tipo de mediação diz respeito às demandas dos meios nos seus aspectos de conteúdos e formas, os gêneros que procuram manter a audiência. Como os receptores atuam ante essas interpelações? Intimamente ligado ao último, outro objeto da mediação é a própria natureza do meio, visto que os sujeitos estabelecem diferentes relações com os meios: televisão, rádio, cinema, jornal, computador. É a diferenciação tecnológica presente no processo de conformação de sentidos.

As instituições sociais que fazem parte da realidade do receptor são os "cenários" de variadas mediações. Família, igreja, escola, bairro, grupos de interesse são lugares privilegiados de apreensão de sentidos das mensagens e de temas. Segundo Orozco Gómez (1994, p. 298), as mediações institucionais atuam como verdadeiras "comunidades de interpretação", pois a partir delas se produzem significados e ocorre o processo da comunicação.

Também fundamentais para o estudo do universo da recepção são as mediações de situação, que se referem às circunstâncias "primeiras" de recepção, às interações nos grupos, aos elementos contextuais específicos do receptor (classe, sexo, nível educacional, origem, etnia). Esses elementos contextuais específicos estendem-se também às motivações e ambições do receptor, às suas visões (pré-conceitos) dos meios, ao tempo livre, valores, etc...

Conhecer as mediações que circundam os sujeitos receptores no processo comunicacional é fundamental na separação dos aspectos presentes e na construção de ferramentas teóricometodológicas tanto para as pesquisas de recepção, como para a Educação em face da Mídia.

Comun. Inf., v. 3, n. 1, p. 80-98, jan./jun. 2000 


\section{Opções metodológicas}

\subsection{As sociologias interpretativas: cotidiano e ator social}

Os estudos em comunicação, durante muito tempo, foram dominados por teorias sociológicas de inspiração estruturalfuncionalista (Mattelart, 1999, p. 131). Um movimento de distanciamento dessas teorias vai em direção à afirmação de metodologias que fazem da pessoa, do grupo, das relações intersubjetivas, novas categorias analíticas.

É a dissensão entre as sociologias que colocam a questão dos "microprocedimentos" e as sociologias estruturais. É revista, no fato social, a questão do ator em relação ao sistema. A pergunta de fundo é: qual é a autonomia da audiência diante dos dispositivos, não só considerando os meios, mas todo o processo?

A experiência do cotidiano é a instância privilegiada das alcunhadas sociologias interpretativas: etnometodologia, interacionismo simbólico, fenomenologia social. O progressivo desenvolvimento acontece a partir dos anos 60 , principalmente nos países anglosaxões. A reviravolta proposta nos estudos é a do indivíduo sobre o coercitivo da sociedade, da prática cotidiana sobre a estrutura. A pedra fundamental da etnometodologia é lançada em 1967 por Harold Garfinkel, valorizando as características e natureza do saber de existência circunstancial dos atores sociais. É um saber fruto da interiorização dos valores da sociedade. O objetivo da etnometodologia é estudar o raciocínio prático em situação de ações comuns.

A "sìtuação adequada" do mundo científico está longe de ser considerada ideal para abordar essas "decisões do cotidiano". A pesquisa da etnometodologia reflete sobre as atividades do dia-a-dia (Garfinkel, apud Mattelart, 1992, p. 132), sendo estas:

1) Numa situação comum:

- Métodos dos membros de um grupo com fins práticos;

- Circunstâncias práticas do conhecimento comum;

2) Na posição do pesquisador:

- Visíveis-racionais-e-relatáveis (pode-se dar conta delas);

- Observáveis e descritíveis.

Comun. Inf., v. 3, n. 1, p. 80-98, jan./jun. 2000 
As operações de interações no cotidiano desse sujeito de um conhecimento especial são equacionadas para esse sujeito dar conta de sua identidade e de suas próprias ações. $O$ contexto e a ação se orientam mutuamente. Logo, o processual é entendido como o momento de conferir sentido às práticas. O esquema da comunicação substitui o da ação (Mattelart, 1999, p. 132).

O interacionismo é uma metodologia incômoda a outras teorias sociais, pois questiona a separação intrínseca nos métodos entre sujeito e objeto, entre indivíduo e outro. Resguardando certo distanciamento crítico em relação ao saber cotidiano, essa abordagem é um retorno reflexivo ao próprio trabalho teórico (Mattelart, 1999, p. 136).

É necessário compreender a medida da inscrição do trabalho teórico nas redes de interação. A isenção científica é substituída pela vigilância, num desafio que questiona o lugare as perspectivas dos atores na interpretação do mundo. Problematiza-se o método de observação participante não somente como ação, mas como forma de obtenção de conhecimento.

\subsection{Adolescência e interesse: as primeiras mediações de um processo comunicativo}

A escolha do público que definiria a audiência de composição do grupo receptor dependeu de uma série de considerações sobre vários aspectos. Em primeiro lugar, a escola de Ensino Médio escolhida foi o Centro Federal de Educação Tecnológica-CEFET, nomeado até 1997 como Escola Técnica Federal de Goiás. O estabelecimento foi escolhido porque constitui-se um centro de referência em ensino de qualidade e gratuito em Goiânia e no Estado de Goiás. Na tabela a seguir, veja o universo de alunos do $1^{\circ}$. ano médio do CEFET (1999):

Comun. Inf., v. 3, n. 1, p. 80-98, jan./jun. 2000 
Tabela 1

\begin{tabular}{|c|c|c|c|c|c|c|c|c|}
\hline $\begin{array}{c}\text { Turmas de } \\
\mathbf{1}^{\circ} \text { ano } \\
\text { Sexo }\end{array}$ & 2150-A & 2150-b & 2150-C & 2150-D & 2150-E & 2150-F & Total & Percent. \\
\hline $\begin{array}{c}\text { Masculino } \\
\text { Feminino }\end{array}$ & 15 & 25 & 23 & 23 & 20 & 27 & 131 & $54,4 \%$ \\
& 16 & 16 & 17 & 23 & 13 & 110 & $45,6 \%$ \\
\hline $\begin{array}{c}\text { Ano de } \\
\text { Nascimento }\end{array}$ & & & & & & & & \\
\hline 80 & 3 & 3 & 5 & 5 & 3 & 5 & 24 & $9,9 \%$ \\
84 & 13 & 12 & 14 & 8 & 20 & 11 & 78 & $32,4 \%$ \\
85 & 23 & 20 & 19 & 26 & 18 & 23 & 129 & $53,5 \%$ \\
$86 \mathrm{e}$ & 1 & 4 & 1 & 1 & 2 & 1 & 10 & $4,2 \%$ \\
ignorado & 1 & & & & & & & \\
\hline
\end{tabular}

Fonte: Banco de dados UPD - CEFET

Alunos do $1^{\circ}$ ano médio do CEFET (1999)

A dificuldade de trabalho com uma turma específica resumiase ao seguinte: um número excessivo de alunos para a proposta metodológica, somada ao fato de ser inadequado, para a metodologia interacionista, trabalhar com um grupo cuja freqüência nas oficinas deveria ser compulsória.

Resolvemos, então, transformar a dificuldade em um item de análise: as mediações de interesse. Vinte e cinco alunos de diferentes turmas se inscreveram na oficina, demonstrando interesse inicial. Todavia, foi colocada a condição de que deveria haver certa assiduidade. Doze alunos freqüentaram a oficina, sendo que dez alunos foram até o último dia - contabilizando $17 \%$ de média de desistência. Entre os doze participantes que freqüentaram:

- 10 eram do sexo feminino, 02 do sexo masculino;

- 06 eram da turma 2150-D, 03 da turma 2150- A, 02 da 2150$\mathrm{C}$ e 01 da 2150-E;

- 07 nasceram em 85, 04 nasceram em 84 e 01 nasceu em 82.

Comparamos a média do universo escolhido (Tabela 1) com os alunos participantes efetivos da pesquisa. Apesar de o universo ser composto de maioria masculina $(54,4 \%)$, a maioria absoluta dos participantes da oficina foi feminina. As turmas 2150-B e 2150-F não se interessaram, enquanto na turma 2150-D um grupo de amigos se mobilizou para participar da pesquisa.

Comun. Inf., v. 3, n. 1, p. 80-98, jan./jun. 2000 
Entendemos que o interesse foi a primeira pista das mediações presentes no processo comunicativo, analisado e construído na oficina de recepção. $\mathrm{O}$ interesse feminino pela apropriação de tecnologia e conhecimento de informação saltou aos olhos, talvez retratando uma tendência geral de revisão dos papéis de gênero na sociedade contemporânea. $\mathrm{O}$ interesse de um determinado grupo de amigos pela oficina deixa claro o papel crucial que as mediações situacionais têm no interesse pelo processo comunicativo.

\subsection{O perfil do grupo receptor: condições socioeconômicas e hábitos culturais}

No antepenúltimo dia de oficina aplicamos um questionário com o objetivo de melhor compreender a natureza do grupo com que trabalhamos e referenciar a pesquisa de maneira mais específica. Os dados dizem respeito ao grupo de dez estudantes que participaram até o último dia da oficina (tabelas 2 a 4).

Tabela 2

Sexo, idade e situação familiar

\begin{tabular}{|c|c|c|c|c|c|}
\hline Sexo & & Ano de nascimento & & Escolaridade da mãe & \\
\hline $\begin{array}{c}\text { Feminino } \\
\text { Masculino }\end{array}$ & $\begin{array}{c}80 \% \\
20 \%\end{array}$ & $\begin{array}{c}\text { Antes de } 84 \\
84 \\
85\end{array}$ & $\begin{array}{c}10 \% \\
30 \% \\
60 \%\end{array}$ & $\begin{array}{c}\text { Ensino Fundamental } \\
\text { Ensino Médio } \\
\text { Superior }\end{array}$ & $\begin{array}{c}10 \% \\
70 \% \\
20 \%\end{array}$ \\
\hline Residência & & Renda Familiar & & Escolaridade do Pai & \\
\hline $\begin{array}{c}\text { Própria } \\
\text { Alugada }\end{array}$ & $\begin{array}{c}50 \% \\
\text { Cobitação }\end{array}$ & $\begin{array}{c}\text { De 2 a 5 SM } \\
\text { De 5 a 10 SM }\end{array}$ & $\begin{array}{c}20 \% \\
40 \%\end{array}$ & $\begin{array}{c}\text { Ensino Fundamental } \\
\text { Ensino Médio }\end{array}$ & $\begin{array}{c}10 \% \\
50 \%\end{array}$ \\
& $10 \%$ & De 10 a 30 SM & $40 \%$ & $\begin{array}{c}\text { Superior } \\
\text { Não sabe }\end{array}$ & $\begin{array}{c}30 \% \\
10 \%\end{array}$ \\
\hline
\end{tabular}

Podemos notar o nível de vida socioeconômico médio da maioria dos alunos participantes da oficina: imóvel próprio, mais de um carro na família. Entretanto, o grau de escolaridade dos pais não era universitário, para a maioria. As famílias eram numerosas e a minoria dos domicílios possuía computador, enquanto a maioria possuía duas ou mais televisões. O computador estava presente em $40 \%$ dos domicílios, o vídeo e a televisão em $90 \%$. 
É importante notar que nenhum dos estudantes possuía algum tipo de renda, fixa ou eventual. Nenhum participante da oficina trabalhava sequer meio período. Tal fato restringe um pouco os ambientes de influência, entendidos situacionais. Outras atividades que delimitariam os ambientes receptivos do grupo não foram freqüentes. $\mathrm{O}$ acesso às informações era feito, principalmente, por meio de telejornais. A leitura de revistas e jornais escritos teve o mesmo peso e era ocasional.

Tabela 3

Acesso a informações e tecnologias

\begin{tabular}{|clcc|}
\hline Principal veículo informativo & $\%$ & Leitura de Jornal & $\%$ \\
\hline Jornal falado & $60 \%$ & Ocasional & $70 \%$ \\
Jornal escrito & $20 \%$ & Aos domingos & $20 \%$ \\
Revistas informativas & $20 \%$ & Diária & $10 \%$ \\
\hline Principal leitura extraclasse & & Internet em casa & \\
\hline Romances policiais e/ou terror & $40 \%$ & Não & $90 \%$ \\
Contos, romances & $30 \%$ & Sim & $10 \%$ \\
Estudos, textos políticos/ & & & \\
históricos, relatórios & $20 \%$ & & \\
Nenhum & $10 \%$ & & \\
\hline
\end{tabular}

Tabela 4

Outras atividades extraclasse

\begin{tabular}{|cccccccc|}
\hline $\begin{array}{c}\text { Clube ou } \\
\text { Similares }\end{array}$ & $\begin{array}{c}\text { Movimento } \\
\text { Social }\end{array}$ & $\begin{array}{c}\text { Grêmio } \\
\text { Estudantil }\end{array}$ & $\begin{array}{c}\text { Grupo } \\
\text { Religioso }\end{array}$ \\
\hline Com frequência & $0 \%$ & Com frequência & $0 \%$ & Com freqüência & $10 \%$ & Com freqüência & $40 \%$ \\
Às vezes & $20 \%$ & Às vezes & $20 \%$ & Às vezes & $10 \%$ & Às vezes & $30 \%$ \\
Não participa & $80 \%$ & Não participa & $80 \%$ & Não participa & $80 \%$ & Não participa & $30 \%$ \\
\hline
\end{tabular}




\subsection{Oficina de recepção}

O Programa de Recepção Ativa, do Centro de Indagación y Expressión Cultural y Artística-CENECA -, é uma referência no delineamento dos programas ou oficinas de recepção em toda a América Latina. Os fundamentos cotejados no Programa do CENECA direcionam o estudo da recepção numa perspectiva de investigação participante, com a realização de jogos lúdicos e de atividades interativas que explorem a produção, seja individual ou coletiva (CENECA, 1989).

É utilizado um enfoque metodológico lúdico, que não busca o produto acabado da televisão, mas o processual presente como criatividade, do qual as mediações se fundam e delimitam significações. Afinal, a mediação é o próprio jogo de construção de sentido. O jogo é parte importante da vida humana, considerado como uma das gêneses do desenvolvimento da cultura.

As técnicas desenvolvidas utilizam o vídeo em diferentes modalidades e funções, ao mesmo tempo com um uso didático, de provocação e registro das atividades (Ferrés, 1996) ${ }^{1}$ :

Videoprocesso - a câmera de vídeo é pivô numa dinâmica de aprendizagem que propõe aos alunos a criação como sujeitos ativos. O vídeo está disponível nas mãos dos alunos, em atividades propostas de forma lúdica que requerem a participação e a criatividade. $\mathrm{O}$ aparato é compreendido como instrumento lúdico de possibilidade expressiva.

Videoanimação - as atividades relacionadas à câmera têm função motivadora. É fundamental para o estímulo emotivo e de evolução no processo. É uma maneira de atuar em um grupo sensibilizando-o para temas, estimulando a interação entre os membros, um "lugar de encontro" entre pessoas que estão produzindo (na gravação) e refletindo sobre o produzido nos debates (após a visualização do que foi gravado).

Vídeoespelho - as atividades são desenvolvidas de forma a serem avaliadas. Essa função avaliadora pressupõe o registro nas atividades criativas precedentes. É a função fundamental para a coleta de dados do pesquisador, em dois aspectos: como registro das atividades e como provocação ao debate. Os participantes se vêem e tomam consciência, sob diversos pontos de vista, da sua capacidade produtiva, da sua voz, da sua imagem. 
Decidimos, então, construir a oficina em duas etapas distintas, que pudessem abordar a relação partindo do geral para o específico, com o objetivo de aprofundar elementos que estariam concretamente presentes na interpretação do receptor.

\section{Mediações do processo}

\subsection{A apresentação: os primeiros sinais das mediações}

O contato inicial foi muito importante na formação das relações do grupo, que até então só haviam sido estabelecidas entre alguns integrantes da mesma turma. Três momentos dos três primeiros dias de oficina podem ser considerados apresentações:

1. O primeiro dia: apresentação entre os participantes, no formato de uma entrevista. Os alunos foram divididos em dois grupos de três. Cada membro revezou-se nas tarefas de entrevistador, entrevistado e câmera. Nenhum contato anterior foi proposto antes da entrevista. $\mathrm{O}$ objetivo era colocar a priori uma relação que seria mediada pelo meio.

2. O segundo dia: apresentação individual para a câmera. Cada participante formulou uma auto-apresentação e gravava diretamente para a câmera. Em seguida, todos assistiram à apresentação e conversaram sobre o que gostaram ou não. O objetivo era discutir que relação se estabelecia nesse contato com a tecnologia e qual foi a reação de cada pessoa: desconforto, nervosismo.

3. O terceiro dia: apresentação da última participante que se juntou ao grupo. A tarefa proposta foi a preparação de uma entrevista com a participante recém-chegada. Todo o grupo se reuniu e dividiu tarefas. $\mathrm{O}$ objetivo era observar a capacidade de trabalho em grupo.

No primeiro contato, o entrevistador deveria criar suas perguntas, sendo que pelo menos dois itens deveriam ser perguntados: Quem era a pessoa? Quais alguns dos hábitos televisivos?

As perguntas variaram bastante, mas podem ser divididas em dois blocos principais:

\section{Sobre a televisão:}

Onde você assiste à TV?

Quanto tempo assiste à TV?

Comun. Inf., v. 3, n. 1, p. 80-98, jan./jun. 2000 
Qual é a posição que vê TV?

Quais programas você mais vê?

Que tipo de filme que você mais gosta?

Com quem você vê TV?

Você prefere ver TV ou ir à Igreja?

Sobre o entrevistado:

Você gosta da escola?

Você gosta dos professores?

Qual o professor que mais gosta?

$O$ que faz no fim de semana?

O que você mais gosta de fazer?

Você tem plano de fazer curso na faculdade?

Qual é a sua religião?

Podemos notar que as perguntas relativas à televisão abordaram principalmente as preferências televisivas e a situação de recepção. Entre as perguntas sobre quem era o entrevistado, vários tipos apareceram, mostrando quais eram os interesses principais dos adolescentes: preferências, escola, diversões, futuro. Estes tipos de perguntas demonstram quais as pautas presentes no dia-adia dos alunos. Já são pistas importantes sobre quais mediações estão presentes no cotidiano.

Perguntada sobre o que gostava na área de televisão, uma participante revela uma posição de franca abertura em relação ao meio:

Eu gosto de tudo um pouco... É uma arte, uma verdadeira arte... Você demonstra tudo que tem para falar tudo: publicidade, entrevista, novela. Tudo é meio que... é arte.

$(\text { Carolina })^{2}$

A síntese sobre o exercício de auto-apresentação do segundo dia revelou alguns aspectos de como os adolescentes relacionaram a autoestima com a própria imagem na televisão. A maioria não gostou da própria imagem e demonstrou nervosismo ao ser filmada. As risadas durante a gravação foram constantes. A relação com a tecnologia continua presente como uma mediação: "Eu me decepcionei com a minha imagem. Eu imaginava uma coisa totalmente diferente, porque você se ver no espelho e se ver na câmera é outra história" (Cássia).

Comun. Inf., v. 3, n. 1, p. 80-98, jan./jun. 2000 
O terceiro momento de contato na apresentação do grupo mostrou que cada integrante se situava de maneira diferente na divisão de tarefas: uns preferiam formular perguntas, uma participante dispôs-se prontamente a ser a entrevistadora. Mas a maioria queria mesmo era operar a câmera. $\mathrm{O}$ vídeo como instrumento motivador cumpriu sua função.

\subsection{A TV e a primeira pessoa}

A noção de "primeira pessoa" do subtítulo diz respeito aos módulos Eu e a TV e Eu e a notícia. A primeira pessoa, no caso, está remetendo também ao "nós" presente nos grupos, onde permeiam as situações, o cotidiano, as instâncias do processo comunicativo na perspectiva da recepção.

$\mathrm{O}$ "Eu", primeira pessoa, quer nomear:

a. Individual - caracterizado por mediações psicológicas, de interesse, específicas e que dizem respeito ao particular;

b. Grupal - caracterizado por mediações de referência (gênero, etnia) e mediações situacionais (grupo da oficina), também específicas, porém compartilhadas pelos indivíduos;

c. Institucional - caracterizado por mediações prédeterminadas (família, sala de aula na escola), das quais participam os sujeitos, sendo comum a diferentes indivíduos.

A recepção só pode ser entendida na opacidade dos vários tecidos que a cobre. Esses tecidos são de variadas naturezas e revelam relações diversas e por vezes conflituosas. Como exemplo, encontramos uma situação curiosa no decorrer da oficina. Os participantes, indivíduos pertencentes ao mesmo grupo de recepção, discordavam entre si sobre o grau de influência da televisão, quando não a mesma pessoa expressava opiniões contraditórias.

As perguntas feitas no primeiro exercício, em que opinavam sobre a TV, nos $3^{\circ}$ e $4^{\circ}$ encontros, seguiram a mesma lógica do primeiro dia:

"-Você acha que a televisão influencia a nossa cultura?

- Sim, influencia. Eu acho que sim. Influencia muito.

- Como? Por quê?

- Igual assim: tem muita gente que não tem aquela cultura, mas

Comun. Inf., v. 3, n. 1, p. 80-98, jan./jun. 2000 


\section{4}

então passa a ver televisão. Então, eles vão passar a fazer aquilo que vêem na televisão" (Aline entrevista Leonardo).

Contrapondo a esta visão, outra participante se posiciona de maneira distinta. O que está em discussão, no caso, é o consumo incentivado pela TV: "Mesmo que a televisão fale que é bom, o professor pode... o seu amigo ou o seu colega... porque eles também estão te influenciando com isso... podem falar que é ruim. Você pelo menos tem a consciência de que algumas pessoas não acham com aquilo que está passando na TV (...) Não é porque você vê televisão que você é influenciado pela televisão" (Katy).

Há uma passagem clara do individual ao grupal, no processo de recepção. Isto pôde ser verificado no exercício do primeiro dia, quando os seis alunos presentes foram instados a dar notas de 0 a 5 para a $\mathrm{TV}$, de acordo com asserções específicas. O processo coordenado foi o seguinte:

1) Distribuição das fichas de preenchimento individuais, garantindo sigilo entre as notas;

2) Recolhimento das fichas individuais e formação de grupos de discussão;

3) Distribuição da ficha de preenchimento coletiva para nota de consenso;

4) Comparação entre as notas individuais e coletivas no quadro.

As médias aritméticas, em geral, não coincidiram com a nota do grupo. Geralmente, as notas cresceram após a discussão, demonstrando que o grupo pode emitir uma opinião mais soberana sobre TV do que o indivíduo até então atomizado.

Os exercícios de simulação de situação de TV, trabalhados no $4^{\circ}$. e $5^{\circ}$. encontros, resultaram em algumas situações exemplares criadas pelos participantes:

- Duas pessoas assistindo à TV: conflito por troca de canal.

- Dois estudantes conversando sobre programação, malhação e filmes na escola.

- Pai e filho vêem futebol; em seguida, mãe e filha chegam querendo ver novela: briga em casa.

Na síntese, os comentários sobre simulações das cenas concordaram que se aplicava. As situações comentavam o cotidiano, princi-

Comun. Inf., v. 3, n. 1, p. 80-98, jan./jun. 2000 
palmente familiar, de recepção, com suas mediações presentes. Conflitos e personagens presentes na relação com a TV mostraram-se importantes.

\subsection{Mediações e referências de sentido}

As referências de sentido são mediações que apareceram principalmente no módulo Eu e a Notícia. Essas referências também aparecem na multiplicidade de composição e não devem ser entendidas separadamente. Destacamos alguns exemplos:

Uma participante fala sobre o papel do professor e certos termos técnicos de economia que aparecem na TV, que parecem incompreensíveis ao grande público: "Eu conheço porque a minha professora de história... a gente discutiu muito sobre isso em classe. Mas se eu não tivesse a professora que eu tive, eu não ia saber (...) A professora tinha um programa que era o seguinte, chamado diário de história: você tinha de ler revista, jornal e ver televisão. No final do mês, você tinha que pegar quatro notícias e entregar em forma de um trabalho para ela. Tinha que ter importância, assim... não podia ser assunto ligado a religião ou fofoca" (Ana Lívia).

Outra participante fala sobre o papel dos professores como mediadores nos programas informativos: "Eu tive uma aula de Geografia e o professor falou que notícia é que nem Geografia: (...) tem que sempre estar informado do que está acontecendo". (Carol).

O professor constitui, no ambiente escolar, uma referência de sentido de presença constante. Entre os estudantes, todos manifestaram mais apreço ou se lembraram de professores que buscavam abordagens diferentes ao tematizarem a televisão ou a relacionavam diretamente ao ensino da sua disciplina em particular.

Outra participante fala sobre notícias no Jornal Nacional: "Eu acho que eles põem um espaço muito grande para uma notícia sem importância. Dois minutos para a escalação da seleção brasileira (...) é muito tempo para pouca coisa. Coisas mais importantes, coisas que interessam mais... sei lá... Por que no dia-a-dia você vai querer saber da escalação da seleção brasileira?" (Lina).

A mediação referencial presente em exemplos como esses é exatamente a particularidade comum dos estudantes: adolescência. Afinal, eles se perguntam, o que interessa realmente para cada pessoa

Comun. Inf., v. 3, n. 1, p. 80-98, jan./jun. 2000 
nessa idade? A informação na TV é colocada na perspectiva da referência de geração.

Em resumo, os outros principais temas presentes nas discussões, entendidos como mediações de referência, foram: temas controversos na audiência (contextual ao assunto da semana), violência, consumismo, hábitos e situações televisivas na família e sexualidade.

\section{Considerações finais}

Esta pesquisa conseguiu alcançar o objetivo proposto de investigar a recepção no Ensino Médio e as mediações presentes nas diversas instâncias relacionais, realizando uma revisão teórico-metodológica e coletando os dados na Oficina de Televisão e Informação.

- Propondo uma revisão teórica, já que os estudos de recepção devem esclarecer os conceitos e os paradigmas que utilizam, buscando a passagem do mapa noturno a que se refere Martín-Barbero (1997) para um mapa diurno, conceitualmente mais bem delimitado. Entendemos que já estamos no contexto desse aprimoramento;

- Propondo uma utilização empírica do conceito de mediação, ou melhor, múltiplas mediações, no sentido de utilizar o aparato teórico-metodológico acumulado tanto para investigar quanto para educar;

- Propondo uma busca de metodologias adequadas às duas primeiras proposições. Devemos, a partir das experiências anteriores na América Latina, buscar os procedimentos metodológicos adequados ao contexto específico de cada pesquisa.

Os resultados deste trabalho indicam que o campo da recepção relacionado à educação formal é uma seara de muitas possibilidades.

Como resultado da nossa investigação, podemos dizer que as mediações no Ensino Médio devem ser compreendidas:

- Na multiplicidade da sua natureza, pois o aluno está presente em diferentes temporalidades;

- A partir da atividade produtiva do sujeito receptor, inserido num determinado contexto;

- Numa relação fundamental entre professor-aluno, sendo que o primeiro é uma referência de sentido para o segundo;

Comun. Inf., v. 3, n. 1, p. 80-98, jan./jun. 2000 
- Na situação ambiente escolar, ampliando para outras situações não menos importantes: ambiente familiar e grupos de interesse.

Trata-se, pois, de conclusão que envolve dois aspectos: educativo e investigativo, que rompem com a concepção do processo por etapas, da passividade do receptor. A pesquisa procurou, enfim, constituir-se num mapa diurno tanto para educadores, como para outros pesquisadores.

\section{Abstract}

This article deals with the theory of reception, that aims at understanding the communicative processes and the receptor's construction of meaning in the public school (CEFET). It has as its basic assumption that the mass communication are not mere means to transport information, but, instead, reveal cultural meanings created in a certain historical period.

Key words: mass communication, reception, audience, media education.

\section{Notas}

1. As modalidades e funções expostas foram trabalhadas a partir da taxonomia proposta por Ferrés (1996). Todavia, o próprio estudioso explica que as diferenciações são apenas operacionais, pois na prática o que ocorre é a interação das funções. A sistematização é uma maneira de estruturar coerentemente as possibilidades do aparato tecnológico.

2. Os nomes mencionados foram substituídos por outros para preservar a identidade dos participantes da pesquisa.

\section{Referências}

CENECA. Unidades de Capacitación en recepción Activa de TV. Santiago, Chile, 1992.

CERTEAU, Michel. A invenção do cotidiano 1 : Artes de fazer. Petrópolis, RJ: Vozes, 1994.

COHN, G. Comunicação e Indústria Cultural. São Paulo: T. A. Queiroz, 1987. FERRÉS, Joan. Televisão e Educação. Porto Alegre: Artes Médicas, 1996. . Vídeo e Educação. Porto Alegre: Artes Médicas, 1996.

FREIRE, Paulo. Pedagogia do oprimido. Rio de Janeiro: Paz e Terra, 1981. . Educação como Prática da Liberdade. Rio de Janeiro: Paz e Terra,

1969.

MARTIN-BARBERO, Jesus. Dos meios às mediações, comunicação, cultura e hegemonia. Rio de Janeiro: UFRJ, 1997.

Comun. Inf., v. 3, n. 1, p. 80-98, jan./jun. 2000 


\section{8}

MATTELART, Armand ; MATTELART, Michèle. História das Teorias da Comunicação. São Paulo: Edições Loyola, 1999.

MELO, J. M. Teoria da comunicação: paradigmas latino-americanos. Petrópolis, RJ: Vozes, 1998.

OROZCO GÓMEZ, Guillermo. La Investigación de la Recepción y la Educación para los Medios: hacia una articulación pedagogica de las mediaciones en el processo. In: UNESCO; CENECA. Educación para la Comunicación. Santiago, Chile, 1992

Uma pedagogia para os meios de Comunicação. Comunicação \& Educação, São Paulo, n.12, p. 77-88, maio/ago. 1998.

SIGNATES, Luiz. Estudo sobre o conceito de mediação. Revista Novos Olhares, São Paulo, n.2, p.37-49, ago./dez. 1998.

SILVA, Magno Medeiros. Educação face à Mídia: interacionismo e mediações. Comunicação \& Educação, São Paulo, n.12, p.266-282, maio/ago. 1998.

SOARES, Ismar de Oliveira. Teoria y prática de la comunicación: incidencia sobre los proyectos de educacion para los medios en la America Latina. In:UNESCO ; CENECA. Educación para la Comunicación. Santiago, Chile, 1992.

. A Comunicação nas novas diretrizes curriculares para o ensino médio. Comunicação \& Informação, Goiânia, v.1, n.2, p.229-233, jul./dez. 1998. Comunicação/ Educação: a emergência de um novo campo e o perfil de seus profissionais. Contato, Brasília, n.2, p.19-74, jan./mar. 1999.

SOUSA, Mauro W. (Org.). Sujeito, o lado oculto do receptor. São Paulo: Brasiliense, 1995.

. A Recepção sendo reinterpretada. Revista Novos Olhares, São Paulo, n.1, p.39-46, jan./jun.1998.

UNESCO; CENECA. Educación para la Comunicación, manual latinoamericano de Educación para los Medios de Comunicación. Santiago, Chile, 1992.

WHITE, Robert. Recepção: a abordagem dos estudos culturais. Comunicação \& Educação, São Paulo, n.12, p.57-76, maio/ago. 1998.

WOLF, Mauro. Teorias das comunicação. Lisboa: Editorial Presença, 1995.

Comun. Inf., v. 3, n. 1, p. 80-98, jan./jun. 2000 